\title{
Analysis of Improving Students' Physics Conceptual Understanding through Discovery Learning Models Supported by Multi-representation: Measurement Topic
}

\author{
La Sahara $^{1}$, Nafarudin ${ }^{2}$, Suritno Fayanto ${ }^{3 *}$, Babajanova Asal Tairjanovna ${ }^{4}$ \\ ${ }^{1}$ Department of Physics Education, Halu Oleo University \\ Jl. H.E.A Mokodompit, Kendari, Southeast Sulawesi, Indonesia \\ ${ }^{2}$ Physics Teacher in Public High School 1 Kendari, \\ Jl. Mayjen Sutoyo, Kendari, Southeast Sulawesi, Indonesia \\ ${ }^{3}$ Physics Teacher in Private High School Tahfidzul Qur'an Mu'adz Bin Jabal Kendari \\ J1. M. Jasin, Kendari, Southeast Sulawesi, Indonesia \\ ${ }^{4}$ Department of Information Technology, Tashkent University of Information Technologies \\ 108 Amir Temur Avenue, Tashkent 100200, Uzbekistan \\ *Email: suritnofayanto@gmail.com
}

\begin{tabular}{|c|c|}
\hline Article Info & ABSTRACT \\
\hline $\begin{array}{l}\text { Article History } \\
\text { Received Nov 5, } 2020 \\
\text { Accepted Dec 27, } 2020 \\
\text { Published Dec 31, } 2020\end{array}$ & \multirow{2}{*}{$\begin{array}{l}\text { This study aimed to analyze students' conceptual understanding by using a multi- } \\
\text { representation assisted discovery learning model in measurement. This research was } \\
\text { conducted in Public High School } 1 \text { Kendari. This research is a quasi-experimental } \\
\text { study using a one-group pre-post test design. The research method consisted of a } \\
\text { conceptual comprehension test using a caliper and a screw micrometer in an essay in } \\
\text { the form of a multi-representational test on long measurements. The analysis showed } \\
\text { an increase in conceptual understanding between the pre-test and post-test with an } \\
\text { average pre-test score of } 16.24(\mathrm{SD}=14 \text { ) and a post-test of } 61.4(\mathrm{SD}=21) \text {. These } \\
\text { results indicate an increase in students' understanding of concepts after learning with } \\
\text { an average N-gain increase of } 0.5(\mathrm{SD}=0.2) \text { in the medium category. It also obtained } \\
\text { the most significant increase in students' understanding of the indicators mentioned } \\
\text { parts caliper and micrometer with an N-gain average of } 0.6 \text { in the medium category. }\end{array}$} \\
\hline $\begin{array}{l}\text { Keywords: } \\
\text { Conceptual understanding } \\
\text { Discovery learning } \\
\text { Multi-representation }\end{array}$ & \\
\hline $\begin{array}{l}\text { ticle: } \\
\text { afarudin, }\end{array}$ & $\begin{array}{l}\text { Tairjanovna, "Analysis of Improving Students' Physics Conceptual } \\
\text { odels Supported by Multi-representation: Measurement Topic," Indones. }\end{array}$ \\
\hline
\end{tabular}

\section{Introduction}

The role of multi representation in learning is an essential topic in educational research, and representation in physics learning plays an essential role in explaining natural phenomena. Students can understand well a topic learned is presented in a form that is easy to learn. In textbooks, the presentation of natural phenomena in physics usually expressed in the form of various representations such as text, diagrams, graphs, and mathematical equations, tables, charts, symbols, and this used to understand and study physics, as well as to convey the ideas and concepts it has [1-4].

Besides, representations help improve students' understanding of physics problems, create bridges between mathematics and verbal or text representations, and help students develop ideas that give mathematical symbols meaning [5]. Physics is a branch of science that studies matter and energy-related natural phenomena. By the interaction of different physical quantities, natural phenomena are created. Physics is a part of natural science with some elements [6,7]. Physics often involves modeling real-world physical phenomena using external representations that range from concrete to abstract forms: pictures, diagrams, words, graphs, and equations [3], [8].

Given the importance of understanding physics's content by students, teachers, and students' concerns should always be logical mastery and student learning progress in physics. Students can see how their knowledge can be conveyed by reflecting on what is used in solving the problem. It will not be difficult for learners who already understand physics's meaning to communicate their understanding in the form of different representations [6]. Martaida et al. [9] reported that one of the problems in education, especially in science subjects, was the learning process's weakness. Students are less motivated to explore their information, but students ask to recall what the teacher has given them. Consequently, students can not solve the problems that occur, especially if the issue is related to the definition of science.

The learning system tends to approach mathematics to get stuck after the mathematical process without understanding physics concepts. Therefore, we need an 
alternative learning model that can enable students to build their knowledge, one of which is the discovery learning model.

Discovery learning is a model for developing active student learning by finding out and investigating so that the results will last a long time in memory, not easily forgotten by students $[10,11]$. The advantage of the discovery model of learning is a learning process based on problem-solving [12]. With this model, students can be more intense in solving problems, making it useful for life in the future [13]. Besides, discovery learning focuses on solving a problem relevant to current developments required to think about society's problem-solving. Therefore, discovery-learning needs to be actualized in real life so that students can respond to more complex life problems. Ansori et al. [14], in their study, reported that implementing the discovery learning model can support students to think critically. Besides, applying the learning discovery made the children learn to think the analysis and try to solve the problems they face themselves [9], [15].

The combination of multi-perception based knowledge to students can optimize the role of discovery learning models. Multi representation is a model that rerepresents the same concept in several different formats. Some representation types may be terms, images, diagrams, graphs, simulations of machines, and mathematical equations in physics. Multi-representation can help learners understand and construct a concept, solve problems, help solve problems, and help solve problems [16,17]. In developing knowledge of scientific concepts and processes, Setyandaru et al. [18] argue that developing science learning in schools requires understanding and connecting verbal, visual, and mathematical representations. In his research, Sunyono and Meristin [19] argued that multiple representationbased learning could enhance students' conceptual understanding of high school chemistry materials compared to discovery learning. Meanwhile, Altan and Eksi [20] reported using several representations to enhance learners' conceptual understanding of energy concepts, such as tables, data-meaning tables, conceptual change texts, concept maps, and analogies.

The solution proposed to solve this problem is to choose models, methods, techniques, or learning approaches with learning paradigms that emphasize students' superiority or behavior in response to different facts and science learning issues (student-centered learning). The exploratory learning model can accommodate all of these things. Discovery learning is a model that promotes the active participation of each student by prepared issues presented by the instructor to discover the concepts and values individually or in groups. According to the specified target, the teacher's task in this model is to direct students with a few roles in seeking concepts and principles.

To solve this issue solution proposed is to choose models, methods, strategies, or learning approaches of learning paradigms that emphasize students' dominance or action in learning in response to various facts and problems of science learning (student-centered learning). A learning model that assumes that all these items can be accommodating is the learning model for exploration. Discovery learning is a model that facilitates each student's active involvement through the teacher's prepared questions to explore the concepts and values individually or in groups. In this model, the teacher's job is to direct students with a few roles to look for concepts and principles according to the goal defined.

Several researchers have studied the use of multirepresentation based discovery learning models. Puspitasari et al. [21] reported that the guided discovery learning model accompanied by multi-representation student worksheets based on problem-solving could improve students' conceptual understanding. Meanwhile, Ummu et al. [22] argued that applying a multiperception-based discovery learning model could improve students' conceptual understanding by a percentage of $90 \%$.

However, based on the results of searches using google scholar, Eric, and ProQuest, it is still rare to explain in detail the use of multi-representation with the discovery learning model, especially on the topic of measurement. In this study, researchers focused on multiperception on measuring instruments in the form of calipers. This selection is due to the lack of literature sources that examine multi-perception on several measuring instruments.

Therefore, researchers are interested in studying students' conceptual understanding through models of discovery learning supported by multiple representations from what has been mentioned. This study aims to analyze and provide an overview of students' conceptual understanding based on multi-representation with discovery learning models on measurement.

\section{Theory}

\section{Concept Understanding}

Understanding is the keyword in the learning. According to Berns and Erickson [23], understanding is an absolute prerequisite for high cognitive abilities, application, analysis, synthesis, and evaluation in a learning domain. According to Amien [24], a concept is based on relevant experiences that can be generalized to form a concept.

Physics is a discipline that needs more comprehension than memorization, so the ability to use three principal points of physics, namely concepts, laws or principles, and theories, is the key to success in studying physics. In learning physics, the ability to conceptualize physics is an absolute requirement in achieving the success of learning physics. According to Bloom, the taxonomy of teaching objectives in the cognitive realm consists of six levels: remember, understand, apply, analyze, evaluate, and create. Competence is characterized by learners' ability to understand concepts, formulas, or facts to interpret and restate them with their own words. For example, tasks that fall under this skill summarize the subject matter, 
clarify the fairy tale contents to one's own experience, and include examples of events similar to those mentioned by the instructor.

\section{Discovery Learning}

Discovery learning model of learning based on constructivist learning theories [25]. Learning is the active method of creating context, argument, dialogue, and physical experiences from constructivism. An assimilation process takes place and connects the experiences or knowledge that has been acquired [26].

In discovery learning, students are not given the concept in its final form, but students are encouraged to find the concept. Students build knowledge based on new information and data-sets they used to investigate learning [27]. Participation in finding concepts in learning gives students a more profound impression so that information is stored longer in students' memory. The process of exploring the concepts being taught also gives students the incentive to make more discoveries to improve their learning interest.

Syntax discovery learning consists of six phases as follows: (a). Stimulation, (b).the problem statement, (c). Data collection (d). Data processing, (e). Verification, and (f). Generalization.

\section{Multi-representation}

According to Ainsworth [28], a multi-representation learning environment's conceptual analysis shows three main functions of multi-representation used in learning situations to complement and build conceptual understanding. The first function is to use representations to obtain additional information or support existing and complementary cognitive processes. Secondly, the representation can be applied to restrict the interpretation of the possible. Recently, multi-representation can be used to encourage students to build a deeper understanding of the concept.

Sunyono and Meristin [19] concluded that multirepresentation involves the importance of restating principles that have been taught in different forms and different acts and expressions, such as delivery by word of mouth, gestures, visuals. Therefore, multirepresentation represents the physical processes in various ways; verbal, sketches, diagrams, graphs, and mathematical equations. There are several advantages of using the first representation; representation helps students understand the material as a visual aid to increase perceptual understanding. Second, the representation is a physical nature, bridging between verbal representations with mathematical representations. The representation of a physical nature helps facilitate students in moving from words into mathematical equations.

\section{Method}

This type of research includes experimental research. The research design was made in the form of a pretest-posttest one group design. The experiment was conducted in Public High School 1 Kendari Class X-MIPA on measurement with 36 students. The research instrument consisted of a multi-representation test, as presented in Table 1.

Data collection techniques in the form of a written test and an indicator containing multiple representations, multi-representation based student competency achievement indicators with discovery learning models are presented in Table 2 .

Data analysis techniques consisted of descriptive analysis and categorization and the students' understanding of statistical analysis in which there are test N-gain normalization [29]. Formula descriptive analysis presented in equation (1).

$$
A=\frac{B}{C} \times 100 \%
$$

Symbol $A$ is the total score obtained, $B$ is the score obtained, and $C$ is the maximum score.

\section{Results and Discussion}

Understanding is a manifestation of a person's perception or viewpoint given a problem. An individual is said to understand whether the issues he faces may derive meaning from messages or clues [30]. Understanding representations is meaningful because information on a problem is often represented differently, such as providing visuals information [31-33]. Multirepresentation understanding, namely, students' understanding of visual, verbal, mathematical, pictures, and graphics [34]. Students are expected to master various representations during learning, such as experimental results, conceptual results, formulas, images. It can be seen in Figure 1 that students are more focused on responding to the questions given.

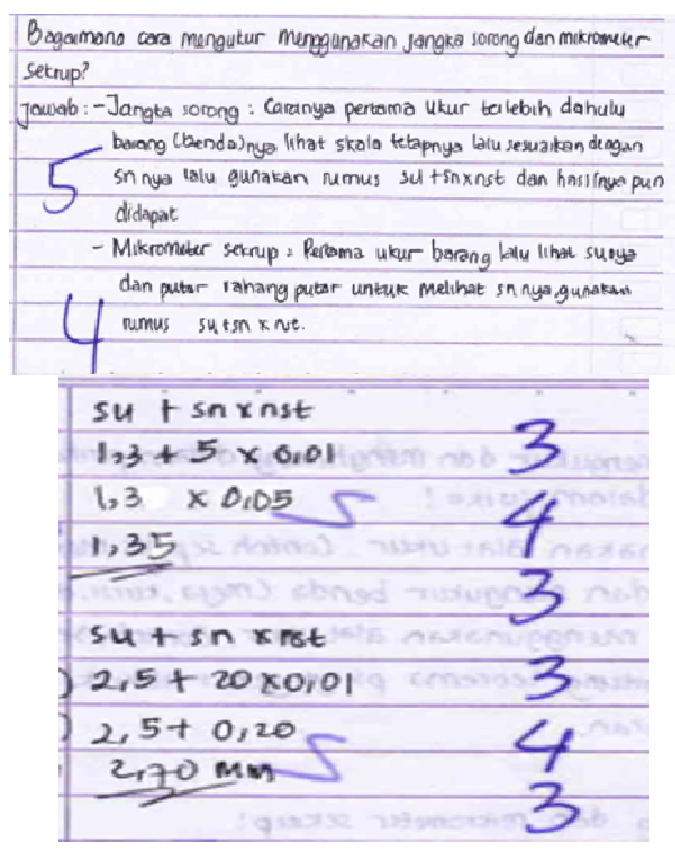

Figure 1. The results of the student's work 
Table 1. The instrument of the student's multi-representation ability

\section{Caliper}

Mathematical symbol The measurement results $=\mathrm{SU}+(\mathrm{Sn} \times \mathrm{NST})$

representations

Text representation

The measurement results on the Calipers are:

1. Viewed and read designation numbers on the main scale (the fixed jaw) adjacent or before zero on a Nonius scale (on a sliding jaw) as readings main scale

2. View and read the scale on the nonius scale, which is precisely in line with the scale on the fixed jaw and multiplied by the smallest unit value on the caliper used as the nonius scale reading. (of all the scales contained in the Nonius scale or on a sliding jaw, there is only one (1) scale that is aligned with the scale on the fixed jaw, scale readings in $\mathrm{mm}$

Representation Image Symbols

3. The measurement result is the sum of the main scale and the nonius scale.

\section{Micrometer}

Text representation

Mathematical representations Representation Image Symbol of

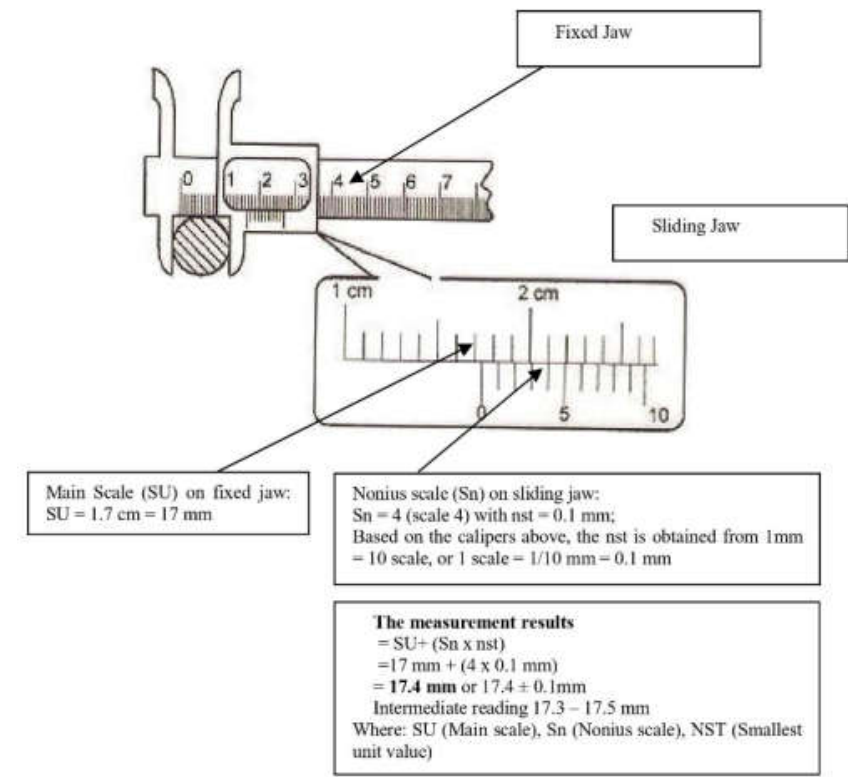

The measurement result on the screw micrometer is:

1. Viewed and read designation scale of the highest rates in the major scale (fixed jaw) near the jaw swivel as reading the main scale

2. View and read the scale on the rotary jaw, which is in line with the horizontal line (horizontal) on the fixed jaw and multiplied by NST (smallest unit value) on the micrometer screw, which is used as the Nonius Scale (SN) reading. Of all the scales contained in the rotary scale or on the rotary jaw, there is only one (1) scale that is entirely in line with the horizontal line on the fixed jaw, with the reading scale in $\mathrm{mm}$.

The measurement results are the sum of the Main Scale and the Nonius Scale.

The measurement results $=\mathrm{SU}+(\mathrm{Sn} \times \mathrm{NST})$

of

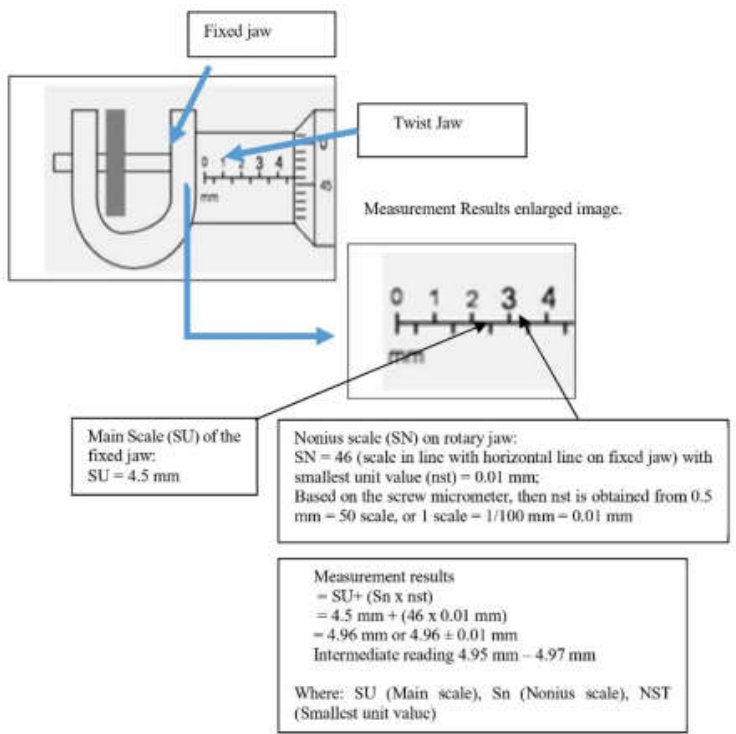


Table 2. A multi-representation based competency achievement indicator with a discovery learning model

\begin{tabular}{|c|c|}
\hline No & Student Competency Achievement Indicators \\
\hline 1 & $\begin{array}{l}\text { Differences measure to calculate and provide an } \\
\text { example }\end{array}$ \\
\hline 2 & Named parts of the caliper \\
\hline 3 & Named parts of the micrometer \\
\hline 4 & The procedure used and the scale reading caliper \\
\hline 5 & $\begin{array}{l}\text { The procedure used and read the scale micrometer } \\
\text { screw }\end{array}$ \\
\hline 6 & $\begin{array}{l}\text { Read the measurement of the length of an object } \\
\text { using a caliper }\end{array}$ \\
\hline 7 & $\begin{array}{l}\text { The reading the results of measurement of the length } \\
\text { of an object using a .micrometre }\end{array}$ \\
\hline
\end{tabular}

Applying multi-representation in the discovery learning model makes it easier for students to understand and question more about the questions given. The findings of the study can be seen as follows, based on the review of research data:

a. The pre-test and post-test application of the discovery learning model assisted by multiple representations of the measurement topic are shown in Table 3.

Table 3. Pre and post-test results in the application of discovery learning model assisted by multi-representation

\begin{tabular}{lcccc}
\hline \multirow{2}{*}{ Test } & \multicolumn{4}{c}{ Value } \\
\cline { 2 - 5 } & min & max & average & SD \\
\hline Pre Test & 2.9 & 55.7 & 16.3 & 13.9 \\
Post Test & 11.4 & 88.6 & 61.4 & 21.0 \\
G & 0.07 & 0.8 & 0.5 & 0.2 \\
\hline \multicolumn{2}{l}{ Note: G (N-gain normalization); SD (Standard Deviation) }
\end{tabular}

It appears in Table 3 that the use of multirepresentation-assisted discovery learning on the subject of measurement increased the comprehension of the measurement content by students from an average of 16.3 to 61.4. After the application model with an increase in $\mathrm{N}$-gain (normalized gain) of 0.55 , which is in the medium category. An increase in N-gain of 0.55 means that students in class $\mathrm{X}_{\mathrm{MIPA}-4}$ experience an increase in learning outcomes by $55 \%$ from the difference between the student's pre-test average score and the ideal or maximum average (or 100) from the test on the topic of measurement.

In other words, the difference between the mean of the initial test and the ideal mean of the students class $\mathrm{X}_{\text {MIPA-4 }}$ is 83.7 (from $100-16.3$ ), and $55 \%$ of 83.7 is 46.04 , or the average value of students after learning increases by 46.04 from the initial test so that the average test eventually to 62.3 (relative value equal to the value of post-test, differ only because of rounding).

Thus, learning multi-representation assisted discovery models can improve students' understanding of the topic of measurement with an average N-gain of 0.55 . Suhandi and Wibowo [35] argued that multirepresentation is one approach that is quite effective to use to instill an understanding of physics concepts. While, Utami et al. [36] reported that multi-representation could improve students' conceptual understanding of physics education in the optical wave course with the Ngain value obtained is 0.69 , which is in the medium category.

Therefore, the use of multi-representations with discovery learning models emphasizes qualitative analysis and the quantitative aspects. The emphasis on multi representation with discovery learning significantly assists students in explaining physical phenomena problem-solving.

b. Total percentage of students $(\%)$ based on the $\mathrm{N}$ gain category.

The distribution of categories for increasing understanding of concepts on the topic of measurement to students' numbers is shown in Table 4.

Table 4. Percentage of total students (\%) based on N- gain category

\begin{tabular}{lc}
\hline \multicolumn{1}{c}{ Category } & Total student $(\mathbf{\%})$ \\
\hline High $(\mathrm{N}-$ Gain $\geq 0.7)$ & 30.6 \\
Medium $(0.3 \leq \mathrm{N}$-gain $<0.7)$ & 50.0 \\
Low $(0<\mathrm{N}-$ Gain $\leq 0.3)$ & 19.4 \\
\hline
\end{tabular}

Table 4 shows that the increase in N-gain usually is distributed; It means that more students $(50 \%)$ have a medium increase or as the gain category, in general, is 0.55 , which is in the medium category. However, the number of students who have a high $\mathrm{N}$-gain category is more significant than those in the low gain category.

c. Description of the distribution of students' pre-test and post-test scores in terms of the aspect of competency achievement indicators on the topic of measurement.

The distribution of student understanding for measures of student competency achievement is shown in Table 5. The distribution of understanding of each indicator on the measurement subject is illustrated in Table 5. In general, based on this data, students had a poor understanding of all indicators before learning. The lowest indicator was using and reading the scale on the initial screw micrometer of 6.9. The extended measurement results using a caliper are also low on the indicator, and the micrometer parts of 10.7 and 11.6 are reported, respectively.

However, students calculate and offer marginally better examples than all other aspects of the distinction aspect. Students' comprehension improved after the learning process, with the highest average being 70.1 in terms of mentioning the caliper components and 67.4 in terms of saying the screw micrometer components. Compared to other aspects, namely 0.63 , these two elements also had the most considerable N-Gain rise.

Table 5 shows that the distinguishing aspect of measuring by counting and giving examples has the lowest N-Gain increase of 0.48 . It also appears that although the invention has been applying aided 
instructional model representation, there are still students who do not understand the concept of the last four indicators (even no value 0 both on the pre-test and posttest).

Table 5. The distribution of students' pre-test and final test scores in terms of $\mathrm{N}$-gain for each indicator of student competency achievement

\begin{tabular}{|c|c|c|c|c|c|c|c|c|c|c|}
\hline \multirow{2}{*}{ No } & \multirow{2}{*}{$\begin{array}{c}\text { Student Competency } \\
\text { Achievement Indicators }\end{array}$} & \multicolumn{4}{|c|}{ Pre Test } & \multicolumn{4}{|c|}{ Post Test } & \multirow[b]{2}{*}{ N Gain } \\
\hline & & $\min$ & $\max$ & Average & SD & $\min$ & $\max$ & Average & SD & \\
\hline 1 & $\begin{array}{l}\text { Differences measure } \\
\begin{array}{l}\text { calculate and } \\
\text { example }\end{array}\end{array}$ & 12.5 & 43.8 & 26.2 & 10.2 & 21.9 & 93.8 & 61.8 & 17.5 & 0.4 \\
\hline 2 & Named parts of the caliper & 0.0 & 66.7 & 19.2 & 25.8 & 25.0 & 100 & 70.1 & 14.6 & 0.6 \\
\hline 3 & Named parts of the micrometer & 0.0 & 66.7 & 11.6 & 22.3 & 16.7 & 100 & 67.4 & 20.8 & 0.6 \\
\hline 4 & $\begin{array}{l}\text { The procedure used and the } \\
\text { scale reading caliper }\end{array}$ & 0.0 & 50 & 20.8 & 19 & 0.0 & 100 & 62.5 & 26.7 & 0.5 \\
\hline 5 & $\begin{array}{l}\text { The procedure used and read the } \\
\text { scale micrometer screw }\end{array}$ & 0.0 & 50 & 6.9 & 15.4 & 0.0 & 100 & 53.5 & 32.3 & 0.5 \\
\hline 6 & $\begin{array}{l}\text { Read the measurement of the } \\
\text { length of an object using a } \\
\text { caliper }\end{array}$ & 0.0 & 69.2 & 10.7 & 17.3 & 0.0 & 100 & 60.1 & 40.3 & 0.5 \\
\hline 7 & Reading the results of & 0.0 & 84.6 & 13.2 & 24.4 & 0.0 & 100 & 59.7 & 40.2 & 0.5 \\
\hline
\end{tabular}
ef the length of an object using a micrometer

Teachers need to increase the awareness of students' multi-representation in different ways of presenting the knowledge to grasp an abstract topic that becomes tangible in all analysis areas [37]. One way to apply learning with multiple representations approach as the research results Widianingtiyas et al. [38] obtained a multi-representation approach can positively influence students' cognitive abilities, including low-level cognitive

and high-level cognitive. Understanding is a form of student cognition in the learning process.

d. Description of the success rate of mastery of the subject matter on the measurement topic

Table 6 and Table 7 shows the number of students based on mastery of the material for measurement subjects, both in the initial and final exams.

Table 6. The distribution number of students (\%) each indicator of conceptual understanding in terms of the success rate of mastery of the material on the initial test (pre-test)

\begin{tabular}{|c|c|c|c|c|c|c|c|c|c|}
\hline \multirow{2}{*}{ No } & \multirow{2}{*}{ Level of success } & \multirow{2}{*}{ Category } & \multicolumn{7}{|c|}{ Indicator codes and number of students (\%) } \\
\hline & & & 1 & 2 & 3 & 4 & 5 & 6 & 7 \\
\hline 1 & Mastering all topics/indicators of subject matter $(100 \%)$ & Excellent & 0.0 & 0.0 & 0.0 & 0.0 & 0.0 & 0.0 & 0.0 \\
\hline 2 & $\begin{array}{l}\text { Most of them master the topic/indicators of the subject matter } \\
(76 \%-99 \%)\end{array}$ & Very good & 0.0 & 0.0 & 0.0 & 0.0 & 0.0 & 0.0 & 5.6 \\
\hline 3 & $\begin{array}{l}\text { Students master } 60 \%-75 \% \text { of indicators/subject topic } \\
\text { materials }\end{array}$ & Good & 0.0 & 16.7 & 5.6 & 0.0 & 0.0 & 2.8 & 2.8 \\
\hline 4 & $\begin{array}{l}\text { Students only master a small portion of the topic/topic } \\
\text { indicator of the lesson }(1 \%-59 \%)\end{array}$ & Lest & 100 & 27.7 & 19.4 & 75 & 22.2 & 50 & 33.3 \\
\hline 5 & $\begin{array}{l}\text { Students do not master the topic/indicator topic of the lesson } \\
(0 \%)\end{array}$ & $\begin{array}{l}\text { Not } \\
\text { master }\end{array}$ & 0 & 55.6 & 75 & 25 & 77.8 & 47.2 & 58.3 \\
\hline
\end{tabular}

Indicator Information: (1) Differences measure to calculate and provide an example; (2) Named parts of the caliper; (3) Named parts of the micrometer; (4) The procedure used and the scale reading caliper; (5) The procedure used and read the scale micrometer screw; (6) Read the measurement of the length of an object using a caliper; (7) Reading the results of measurement of the length of an object using a micrometer

Table 7. The distribution number of students (\%) each indicator of conceptual understanding in terms of the success rate of mastery of the material on the final test (post-test)

\begin{tabular}{|c|c|c|c|c|c|c|c|c|c|}
\hline \multirow{2}{*}{ No } & \multirow{2}{*}{ Level of success } & \multirow{2}{*}{ Category } & \multicolumn{7}{|c|}{ Indicator codes and number of students (\%) } \\
\hline & & & 1 & 2 & 3 & 4 & 1 & 6 & 7 \\
\hline 1 & Mastering all topics/indicators of subject matter $(100 \%)$ & Excellent & 0.0 & 8.3 & 11.1 & 5.6 & 2.8 & 36.1 & 36.1 \\
\hline 2 & $\begin{array}{l}\text { Most of them master the topic/ indicators of the subject } \\
\text { matter }(76 \%-99 \%)\end{array}$ & Very good & 19.4 & 16.7 & 16.7 & 25.0 & 25.0 & 13.9 & 13.9 \\
\hline 3 & $\begin{array}{l}\text { Students master } 60 \% \text { - } 75 \% \text { of indicators / subject topic } \\
\text { materials }\end{array}$ & Good & 30.6 & 69.4 & 55.5 & 36.1 & 25.0 & 5.6 & 2.8 \\
\hline 4 & $\begin{array}{l}\text { Students only master a small portion of the topic/topic } \\
\text { indicator of the lesson }(1 \%-59 \%)\end{array}$ & Lest & 50.0 & 5.6 & 16.7 & 25.0 & 27.8 & 38.8 & 36.1 \\
\hline 5 & $\begin{array}{l}\text { Students do not master the topic/indicator topic of the lesson } \\
(0 \%)\end{array}$ & Not master & 0.0 & 0.0 & 0.0 & 8.3 & 19.4 & 5.6 & 11.1 \\
\hline
\end{tabular}

Indicator Information: (1) Differences measure to calculate and provide an example; (2) Named parts of the caliper; (3) Named parts of the micrometer; (4) The procedure used and the scale reading caliper; (5) The procedure used and read the scale micrometer screw; (6) Read the measurement of the length of an object using a caliper; (7) Reading the results of measurement of the length of an object using a micrometer 
It appears that of the 36 students, the level of comprehension of the students is still in the decent/minimum group below (the level of mastery of materials is below $76 \%$ for all indicators), based on Table 6 and Table 7 before learning. Besides, the indicator uses a micrometer to read the long measurement results. Even more than $50 \%$ of students do not master the content/subject matter on four indicators, namely, mentioning parts of the calipers, mentioning parts of the micrometer, procedures for using and reading the micrometer screw scale reading the length measurement using a screw micrometer.

More than $50 \%$ of the students had a degree of understanding of materials or indicators of more than $60 \%$ (good, excellent, and special categories) after learning, except for differentiating indicators calculated by counting and offering. For instance, no students met a particular category. Moreover, no more students are not mastering the content for the first three indicators after learning. However, there are still students who are not mastering the material for the last four indicators.

It can be observed from this clarification that the implementation of the discovery learning model with multi representations can enhance the comprehension of each indicator in the measuring material by students. As explained, indicators mean $\mathrm{N}$-gain on the subject calculation; all indicators have increased with an average $\mathrm{N}$-gain between $0.48-0.63$.

e. The relationship between initial knowledge and pretest and post-test on measurement topics

The relationship between the original information gained from the basic understanding of physics assessments for class grouping when entering school to understand students on the subject of measurement is presented in Table 8.

Table 8. The relationship between students' initial ability levels with pre-test and post-test on the topic of measurement

\begin{tabular}{clcccc}
\hline No & \multicolumn{1}{c}{ Initial ability level } & \multicolumn{3}{c}{ Average } \\
\cline { 3 - 6 } & & TA & Pre-test & Posttest & N-gain \\
\hline 1 & Groups of students with low abilities & 37.5 & 13.2 & 62.8 & 0.57 \\
2 & Groups of students with medium abilities & 41.4 & 17.2 & 58.0 & 0.52 \\
3 & Groups of students with high abilities & 45.0 & 17.0 & 66.5 & 0.61 \\
& Average total (N=36) & $\mathbf{4 1 . 5}$ & $\mathbf{1 6 . 3}$ & $\mathbf{6 1 . 4}$ & $\mathbf{0 . 5 5}$ \\
& Standard deviation total & $\mathbf{2 . 8}$ & $\mathbf{1 3 . 9}$ & $\mathbf{2 1 . 0}$ & $\mathbf{0 . 2 1}$ \\
\hline
\end{tabular}

The mean comprehension of students on the measurement content tends to be compatible with their initial ability (TA) based on Table 8 . In contrast, the pretest has almost the same mean between students with modest abilities and elevated abilities. In the post-test performance, it can be shown that high-quality students have a higher increase in N-Gain (0.61) compared to the middle and low-quality student classes with an average $\mathrm{N}-$ Gain of 0.52 and 0.57 , respectively.

The rise N-Gain of the high-capacity and lowcapacity groups of students ( 0.61 and 0.57 respectively) can be shown from the data in Table 8 to be higher than the $\mathrm{N}$-gain of the moderate-capable group (0.52). It implies that implementing the multi representation discovery learning model is appropriate for enhancing the comprehension of the measurement content by highcapacity students and low capacity.

These findings indicate that multi representation based learning is effective in increasing the conceptual understanding of students with "low" and "medium" initial abilities [19].

\section{Conclusion}

Based on the explanation of the study, it indicates that there is an improvement in the conceptual comprehension of students with a mean pre-test score of $16.2(\mathrm{SD}=14)$ and post-test $61.4(\mathrm{SD}=21)$ via the multirepresentation aided discovery learning model on the subject of measurement between pre-test and post-test.
These results indicate that the concept is substantially improved with a boost in the un-normalized gain of 0.5 $(\mathrm{SD}=0.2)$ and the intermediate category. By offering representational learning facilities, student communication can be generated, and students can help solve problems and better understand concepts. Moreover, with an average $\mathrm{N}$-gain of 0.63 , an improvement in understanding the principle on the subject of measurement, particularly on the indicators explaining the calipers' sections and the screw micrometers obtained.

\section{Acknowledgment}

The researcher would like to thank Public High School 1 Kendari for facilitating the research to be completed properly. Furthermore, the authors would like to thank Halu Oleo University for the financial support provided to finish this research.

\section{References}

[1] W. Roth, M. K. McGinn, and G. M. Bowen, "How Prepared are Preservice Teachers to Teach Scientific Inquiry?," Journal of Science Teacher Education, vol. 9. pp. 25-48, 1998.

[2] P. Sothayapetch, J. Lavonen, and K. Juuti, "An Analysis of Science Textbooks for Grade 6: The Electric Circuit Lesson," EURASIA J. Math. Sci. Technol. Educ., vol. 9, no. 1, Jan. 2013.

[3] J. Yeo and J. K. Gilbert, "The Role of Representations in 
Students' Explanations of Four Phenomena in Physics: Dynamics, Thermal Physics, Electromagnetic Induction and Superposition," in Multiple Representations in Physics Education, D. Treagust, R. Duit, and H. Fischer, Eds. Springer, 2017, pp. 255-287.

[4] S. Nulhaq and A. Setiawan, "Influences of Multiple Representations in Physics Learning to Students in Understanding Physics Material and Scientific Consistency," Int. Conf. Innov. Eng. Vocat. Educ., no. Icieve, 2015, pp. 235-238, 2016.

[5] Ulvarina, "Penggunaan Multirepresentasi pada Pembelajaran Konsep Gerak untuk Meningkatkan Kemampuan Memahami dan Memperkecil Kuantitas Miskonsepsi Siswa SMP," Universitas Pendidikan Indonesia, 2010.

[6] Y. Theasy, Wiyanto, and Sujarwata, "Multi-representation Ability of Students on the Problem-solving Physics," $J$. Phys. Conf. Ser., vol. 983, no. 1, pp. 1-7, 2018.

[7] Y. Theasy, Wiyanto, and Sujarwata, "Identifikasi Kesulitan Belajar Fisika Berdasarkan Kemampuan Multi Representasi," Phys. Commun., vol. 1, no. 2, pp. 1-5, 2017.

[8] D. Wong, S. P. Poo, N. E. Hock, and W. L. Kang, "Learning with Multiple Representations: An Example of a Revision Lesson in Mechanics," Phys. Educ., vol. 46, no. 2, pp. 178-186, 2011.

[9] T. Martaida, N. Bukit, and E. M. Ginting, "The Effect of Discovery Learning Model on Student's Critical Thinking and Cognitive Ability in Junior High School," IOSR J. Res. Method Educ., vol. 7, no. 6, pp. 1-8, 2017.

[10] D. Desyandri, M. Muhammadi, M. Mansurdin, and R. Fahmi, "Development of Integrated Thematic Teaching Material used Discovery Learning Model in Grade V Elementary School," J. Konseling dan Pendidik., vol. 7, no. 1, p. $16,2019$.

[11] A. Nurahman, W. Widodo, I. Ishafit, and B. O. Saulon, "The Development of the Worksheet Based on Guided Discovery Learning Method Helped by PhET Simulations Interactive Media in Newton's Laws of Motion to Improve Learning Outcomes and Interest of Vocational Education 10th-Grade Students," Indones. Rev. Phys., vol. 1, no. 2, p. 37,2019 .

[12] M. Y. R. T. Kawuri and Suritno Fayanto, "Penerapan Model Discovery Learning terhadap Keaktifan dan Hasil Belajar Siswa Kelas X MIPA SMAN 1 Piyungan Yogyakarta Maria Yosephien," J. Penelit. Pendidik. Fis., vol. 5, no. 1, pp. 1-8, 2020.

[13] E. Nurcahyo, L. Agung S, and D. Djono, "The Implementation of Discovery Learning Model with Scientific Learning Approach to Improve Students' Critical Thinking in Learning History," Int. J. Multicult. Multireligious Underst., vol. 5, no. 3, p. 106, 2018.

[14] Z. Ansori, Wartono, and Sutopo, "Pembelajaran Multi Representasi dengan Pendekatan Empiris, Teoritis dan Animasi untuk Meningkatkan Pemahaman Konsep Siswa," Pros. Semin. Pend. IPA Pascasarj. UM, vol. 2, pp. 345-348, 2017.

[15] F. Fatmawati, L. Sukariasih, S. Fayanto, and H. Retnawati, "Investigating the Effectiveness of Inquiry Learning and Direct Learning Models Toward Physics Learning," Adv. Soc. Sci. Educ. Humanit. Res., vol. 317, no. IConProCS, pp. 260-265, 2019.

[16] E. Erniwati et al., "Analysis of Difficulty of Science Learning-Based Multi-Representation," J. Pendidik. Fis., vol. 8, no. 3, pp. 263-278, 2020.

[17] I. Khairunnisa and Suritno Fayanto, "Physics Teaching: Development of Lectora Inspire with A Multiple-
Representation Approach to Reduce of Misconception," $J$. Dedik. Pendidik., vol. 8848, no. 2, pp. 159-170, 2020.

[18] T. A. Setyandaru, S. Wahyuni, and D. Pramudya, "Pengembangan Modul Pembelajaran Berbasis Multirepresentasi pada Pembelajaran Fisika di SMA/MA," J. Pembelajaran Fis., vol. 6, no. 3, pp. 218 224, 2017.

[19] S. Sunyono and A. Meristin, "The Effect of Multiple Representation-Based Learning (MRL) to Increase Students' Understanding of Chemical Bonding Concepts," J. Pendidik. IPA Indones., vol. 7, no. 4, pp. 399-406, 2018.

[20] M. Altan Kurnaz and C. Eksi, "An Analysis of High School Students' Mental Models of Solid Friction in Physics," Kuram ve Uygulamada Egit. Bilim., vol. 15, no. 3, pp. 787-795, 2015.

[21] V. Puspitasari, Wiyanto, and Masturi, "Implementasi Model Guided Discovery Learning Disertai LKS Multirepresentasi Berbasis Pemecahan Masalah untuk Meningkatkan Pemahaman Konsep Siswa," Unnes Phys. Educ. J., vol. 7, no. 3, pp. 19-27, 2018.

[22] M. A. M. Ummi Kalsum, Saefuddin, "Penerapan Model Discovery Learning Berbasis Multirepresentasi untuk Meningkatkan Keterampilan Berpikir Kritis dan Penguasaan Konsep Ikatan Kimia," J. Pendidik. Kim. Univ. Halu Oleo, vol. 4, no. 2, pp. 117-182, 2019.

[23] R. Berns and P. Erickson, "Contextual Teaching and Learning: Preparing Students for the New Economy," Highlight Zo. Res., no. 5, pp. 1-8, 2001, [Online]. Available: $\quad$ http://citeseerx.ist.psu.edu/viewdoc/ download?doi=10.1.1.453.3887\&rep=rep1\&type=pdf.

[24] M. Amien, Buku Pedoman Laboratorium dan Petunjuk Praktikum Pendidikan IPA Umum. Jakarta: Departemen Pendidikan dan Kebudayaan, 1988.

[25] J. C. Anyafulude, "Effects of Problem-Based and Discovery-Based Instructional Strategies on Students' Academic Achievement in Chemistry," J. Educ. Soc. Res., vol. 3, no. 6, pp. 105-112, 2013.

[26] C. T. Anni and A. Rifa'i, Psikologi Pendidikan. Semarang: Uness Press, 2011.

[27] T. De Jong and W. R. Van Joolingen, "Scientific Discovery Learning with Computer Simulations of Conceptual Domains," Rev. Educ. Res., vol. 68, no. 2, pp. 179-201, 1998.

[28] S. Ainsworth, "The Educational Value of MultipleRepresentations," Vis. Theory Pract. Sci. Educ., pp. 191208, 2008.

[29] R. R. Hake, "Analyzing Change/Gain Scores. Dept. of Physics Indiana University," 1999.

[30] Suwanto, Pengembangan Bahan Ajar Tematik (Tinjauan Teoritis dan Praktis). Jakarta: Kencana Publisher, 2014.

[31] B. Waldrip, V. Prain, and J. Carolan, "Using Multi-modal Representations to Improve Learning in Junior Secondary Science," Res. Sci. Educ., vol. 40, no. 1, pp. 65-80, 2010.

[32] V. Prain and B. Waldrip, "An Exploratory Study of Teachers' and Students' Use of Multi-Modal Representations of Concepts in Primary Science," Int. J. Sci. Educ., vol. 28, no. 15, pp. 1843-1866, 2006.

[33] Mizayanti, A. Halim, R. Safitri, and E. Nurfadilla, "The Development of Multi Representation Practicum Modules with PhET in Hooke's Law Concept," J. Phys. Conf. Ser., vol. 1460, no. 4, p. 012124, Feb. 2020.

[34] Nizarudin, "Role of Multiple Representations in Mathematical Problem Solving," Int. Conf. Math. Sci. Educ. 2014, vol. 2014, no. Icmse, pp. 163-168, 2014.

[35] A. Suhandi and F. C. Wibowo, "Pendekatan Multirepresentasi dalam Pembelajaran Usaha-Energi dan 
Dampak Terhadap Pemahaman Konsep Mahasiswa," $J$. Pendidik. Fis. Indones., vol. 8, no. 1, pp. 1-7, 2012.

[36] L. S. Utami, N. Wayan, and S. Darmayanti, "Pemahaman Konsep Mahasiswa Fisika Materi Gelombang dan Optik Tahun Akademik 2018/2019," Orbita. J. Has. Kajian, Inovasi, dan Apl. Pendidik. Fis., vol. 5, no. 1, pp. 53-58, 2019.

[37] Hasbullah, A. Halim, and Y. Yusrizal, "Penerapan
Pendekatan Multi Representasi terhadap Pemahaman Konsep Gerak Lurus," J. IPA Pembelajaran IPA, vol. 2, no. 2, pp. 69-74, 2019.

[38] L. Widianingtiyas, S. Siswoyo, and F. Bakri, "Pengaruh Pendekatan Multi Representasi dalam Pembelajaran Fisika Terhadap Kemampuan Kognitif Siswa SMA," J. Penelit. Pengemb. Pendidik. Fis., vol. 01, no. 1, pp. 3138, 2015. 